\title{
Offshore diet of grey seals Halichoerus grypus near Sable Island, Canada
}

\author{
W. D. Bowen, G. D. Harrison \\ Marine Fish Division, Bedford Institute of Oceanography, Department of Fisheries and Oceans, Dartmouth, Nova Scotia, \\ Canada B2Y 4A2
}

\begin{abstract}
Many pinnipeds forage considerable distances from mainland haul-out sites for much of the year, yet little is known about the composition of their offshore diets. This may result in an incomplete and potentially biased view of the diet of wide-ranging species such as the grey seal Halichoerus grypus. On the Scotian Shelf, offshore fish assemblages differ from those nearer the coastal mainland sites and thus we expected that grey seal diets would also differ. We studied the composition of grey seal diets at Sable Island, an offshore site $160 \mathrm{~km}$ east of Nova Scotia, Canada. Otoliths, squid beaks and other hard parts, representing more than 24 types of prey, were recovered from 365 of 393 grey seal faeces collected between July 1991 and January 1993. Despite the large number of taxa found, 3 prey - sand lance Ammodytes dubius (69.2\%). Atlantic cod Gadus morhua (15.5\%) and flatfishes (Pleuronectiformes, $10.7 \%$ ) - accounted for $95.4 \%$ of the estimated wet weight food consumed by grey seals. Despite within-year variation in the species composition of grey seal diets, sand lance was the most important food in all months sampled. Comparisons of prey species abundance in research trawl surveys to that in grey seal diets indicated that more abundant and more widely distributed species accounted for most of the prey eaten.
\end{abstract}

KEY WORDS: Grey seal · Halichoerus grypus · Diet · Prey size · Otolith · Sable Island

\section{INTRODUCTION}

In recent years, considerable effort has been devoted to obtaining quantitative estimates of seasonal and geographic variation in the species composition of pinniped diets (Bailey \& Ainley 1982, Perez \& Bigg 1986, Harkönen 1987, Hammond \& Prime 1990, Olesiuk et al. 1990, Pierce et al. 1990a, Prime \& Hammond 1990, Bowen et al. 1993). Generally these data have been collected from mainland haul-out sites or from sites on coastal islands, with the result that the composition of offshore diets may not be adequately represented. The limitations of such sampling may be of relatively little concern in some species, but they could be a significant source of uncertainty about the composition of the diets in a species with a broad offshore distribution, such as the grey seal Halichoerus grypus, where prey assemblages may differ significantly from those nearer to coastal mainland foraging areas.

In the northwest Atlantic, grey seals inhabit coastal and offshore waters of the continental shelf from the
Gulf of Maine to southern Labrador and the Gulf of St. Lawrence (Mansfield \& Beck 1977). More than $90 \%$ of grey seal births in the northwest Atlantic take place on Sable Island on the Scotian Shelf and on the ice in the southern Gulf of St. Lawrence during the period from late December to early February (Stobo \& Zwanenburg 1990). Returns of tags suggest that grey seals are widely distributed throughout their range outside of the breeding season (Stobo et al. 1990). However, on the eastern Scotian Shelf, a significant fraction of the grey seal population is thought to use Sable Island and surrounding waters throughout the year.

Using data from research vessel surveys, Mahon \& Smith (1989) concluded that the offshore banks of the Scotian Shelf, such as Sable Island Bank, support persistent demersal fish assemblages which differ from the more nearshore areas adjacent to mainland Nova Scotia in both species composition and relative abundance of dominant species. Located approximately $160 \mathrm{~km}$ east of mainland Nova Scotia, Sable Island provides an unusual opportunity to study the offshore diet of grey seals 
on the Scotian Shelf. The maximum daily foraging range of grey seals is about $80 \mathrm{~km}$, therefore, we are confident that our samples come from a different prey assemblage (i.e. the Eastern Banks assemblage; Mahon \& Smith 1989) than samples collected at or near mainland haulout sites (Bowen et al. 1993).

Estimates of pup production in the Gulf of St. Lawrence and censuses of pups conducted on Sable Island indicate that production has been increasing since the late 1960s (Zwanenburg \& Bowen 1990). Pup production on Sable Island increased by more than 20-fold between the early 1960s and 1989 (Stobo \& Zwanenburg 1990, Zwanenburg \& Bowen 1990). The total number of grey seals in eastern Canada has also increased substantially over the past several decades. Zwanenburg \& Bowen (1990) estimated the 1987 population at 106000 seals, with nominal confidence limits of 84000 to 130000 .

The increasing number of grey seals in eastern Canada, coupled with existing information which suggests that commercial species are often consumed by grey seals (Mansfield \& Beck 1977, Benoit \& Bowen 1990, Murie \& Lavigne 1992, Bowen et al. 1993), has highlighted the potential for competitive interactions between grey seals and commercial fisheries. Assessment of these interactions requires reliable quantitative data on the diet of grey seals at both mainland and offshore locations. Few quantitative studies of grey seal diets have been conducted in eastern Canada (Benoit \& Bowen 1990, Murie \& Lavigne 1992, Bowen et al. 1993) and for the most part the samples collected in these studies have come from mainland locations.

The purpose of our study was 2-fold: first, to determine the species composition and size of prey consumed by grey seals offshore, and the extent to which diets might vary temporally; and second, to examine diet composition in relation to the estimates of prey abundance and distribution near Sable Island.

\section{METHODS}

On 8 occasions between July 1991 and January 1993, 393 faecal samples were collected at grey seal haul-out sites on Sable Island, Canada (Fig. 1). Given that grey seals and harbour seals Phoca vitulina generally use different parts of the island and that grey seal faeces are larger than those of harbour seals, we were confident that only grey seal faeces were collected. Individual samples were placed in labelled plastic bags and stored at $-20^{\circ} \mathrm{C}$. Each sample was placed in a jar of water, thawed at room temperature for about $12 \mathrm{~h}$, and then blended for 30 to $60 \mathrm{~s}$ using a Sorvall Omni-mixer to break up the faecal material. The contents of the jar were then poured into a plastic

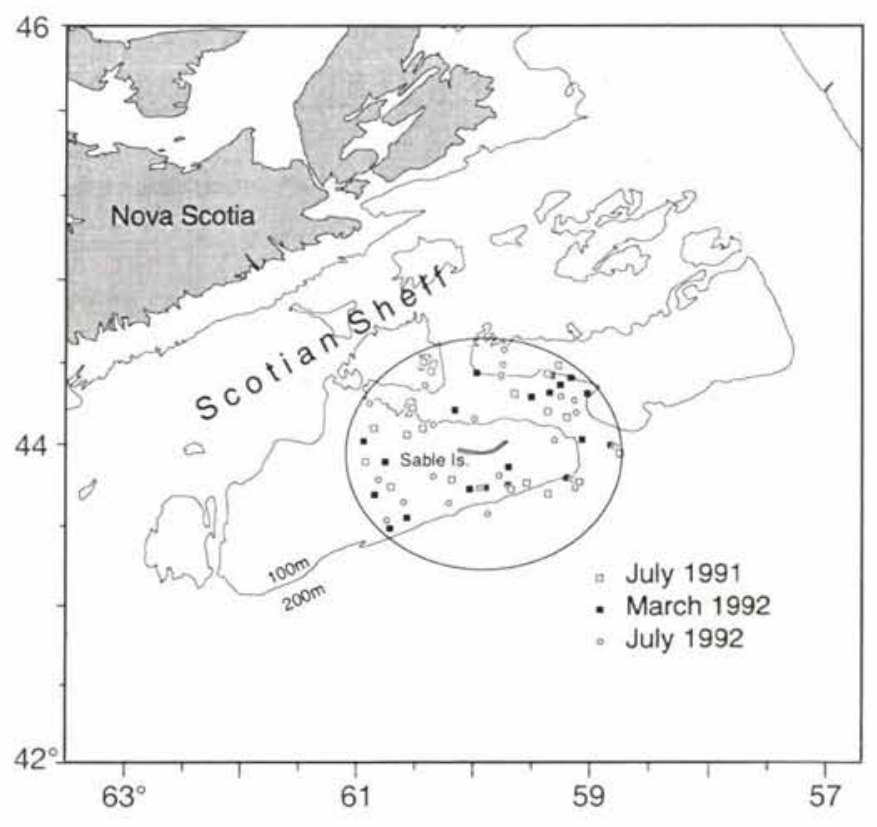

Fig. 1. Location of Sable Island (Canada) on the Scotian Shelf and of research fishing stations, within approximately $78 \mathrm{~km}$ of Sable Island, from research trawl surveys conducted by the Marine Fish Division, Bedford Institute of Oceanography in 1991 and 1992

tray and inspected for the presence of shrimp and other invertebrate remains, some of which tended to float. This solution was poured off, leaving the heavier material which included hard parts such as otoliths and squid beaks. The volume of this material was reduced by gently running water through the tilted tray. The remaining sediment was then examined under a dissecting microscope to maximize the number of otoliths recovered. A photographic print of a micrometer was mounted on the base of the microscope to permit otoliths and squid beaks to be measured to the nearest $0.1 \mathrm{~mm}$. Of the otoliths recovered, only sagittae were counted and measured. Otoliths and squid beaks were transferred to individually labelled vials containing a solution of $70 \% \mathrm{EtOH}, 25 \%$ water and $5 \%$ glycerine for storage. To test the efficacy of our otolith recovery technique, we passed the discarded fluid from 6 scat samples, from which several hundred otoliths had been removed, through a fine $(0.165 \mu \mathrm{m})$ mesh screen and recovered no otoliths or other prey hard parts. Otoliths were identified by comparing them with a reference collection of otoliths from the Scotian Shelf. Red hake Urophycis chuss and white hake $U$. tenuis were lumped in our study because most of the otoliths recovered of these species were small and could not be reliably distinguished. Squid beaks were identified using Clarke (1986). Skates Raja spp. were identified by the thorns found on the dorsal surface of the body of most species. 
We attempted to identify the number of right and left otoliths (and upper and lower squid beaks) of each species to estimate the number of individual prey represented in each sample. Unmatched otoliths and beaks were counted as one prey. In cases of badly eroded otoliths or where large numbers precluded matching the number of left and right otoliths (e.g. sand lance Ammodytes dubius), the total number of otoliths of each species was divided by 2 to derive the number of prey in the sample.

Otoliths are eroded by gastric fluids as they pass through the gastro-intestinal tract. This can bias estimates of prey size and thus the importance of different species in the diet. In this study, we attempted to minimize this problem by not measuring severely eroded otoliths, many of which could not be identified to species in any case. In practice, this meant measuring only those otoliths, regardless of size, with surface features such as the sulcus or lobation relatively intact. These features are usually the first to erode during digestion and are the most reliable indicators of otolith condition.

To estimate fish prey size, otolith length was measured from the anterior edge to the posterior edge through the center (nucleus) of the otolith. In the case of squid, the lower rostral length of lower beaks was measured to estimate prey weight following Clarke (1986). Only 1 otolith or beak was measured for each individual prey. In deriving estimates of total weight of each species consumed, the size distribution of unmeasured otoliths from individual faecal samples within each month was assumed to be equal to that of otoliths which were measured. Regression equations used to estimate prey length and prey weight are given in Table 1. The equations developed in this study are based on fish collected on the Scotian Shelf (Fig. 1).
The large number of sand lance otoliths recovered $(\mathrm{n}=27676)$ made it impractical to consider measuring all of them. To determine a reasonable subsample of otoliths to measure, we applied a components of variance technique for 2-stage sampling described by Snedecor \& Cochrane (1967, p. 528). A total of 6 sand lance otoliths from each of 12 faecal samples were randomly selected and measured to the nearest $0.1 \mathrm{~mm}$. Using an ANOVA, we found that withinsample variability in otolith length $(\mathrm{MS}=0.078$ ) was low relative to the variability among samples (MS = 0.779 ). Using these variance estimates, we determined that measuring a maximum of 5 otoliths per faecal sample was sufficient to limit the SE of the mean to $<0.1 \%$ with $95 \%$ confidence.

To some extent, the diet of grey seals ought to reflect the relative abundance and distribution of prey. An estimate of prey distribution and abundance was obtained from research surveys conducted by the Marine Fish Division, Bedford Institute of Oceanography, on the Scotian Shelf in March and July of the years covered by our faecal collections. Conducted since 1970, these stratified-random surveys use a bottom trawl that is equipped with a 0.25 inch $(6.4 \mathrm{~mm})$ mesh liner to retain small fish that would not be retained by the trawls used in commercial fisheries. Thus, these surveys provide a measure of the abundance and distribution of all sizes of prey that might be available to grey seals. Our current understanding of the structure of demersal fish assemblages on the Scotian Shelf is based on the analysis of 18 of these surveys conducted between 1970 and 1981 (Mahon \& Smith 1989).

To compare the abundance of prey species in bottomtrawl surveys with their importance in the diet of grey seals, we selected only those research fishing stations

Table 1. Regression equations used to estimate fork length (FL) and wet weight (W) from fish otolith length (OL) and squid beak lower rostral length (LRL)

\begin{tabular}{|c|c|c|}
\hline Species & Fork length $(\mathrm{cm})$ & Wet weight (g) \\
\hline Atlantic cod Gadus morhua & $\ln (\mathrm{FL})=3.3138+1.6235 \ln (\mathrm{OL}, \mathrm{cm})^{\mathrm{a}}$ & $\mathrm{W}=0.0124(\mathrm{FL})^{2.93 \mathrm{~b}}$ \\
\hline Haddock Melanogrammus aeglefinus & $\ln (\mathrm{FL})=2.9775+1.5846 \ln (\mathrm{OL}, \mathrm{cm})^{a}$ & $\mathrm{~W}=0.0071(\mathrm{FL})^{3.10 \mathrm{~b}}$ \\
\hline Pollock Pollachius virens & $\ln (\mathrm{FL})=3.2510+1.6251 \ln (\mathrm{OL}, \mathrm{cm})^{\circ}$ & $\mathrm{W}=0.0134(\mathrm{FL})^{2.94 \mathrm{~b}}$ \\
\hline Silver hake Merluccius bilinearis & $\ln (\mathrm{FL})=3.0111+1.0276 \ln (\mathrm{OL}, \mathrm{cm})^{\mathrm{a}}$ & $\mathrm{W}=0.0059(\mathrm{FL})^{3.05 b}$ \\
\hline White hake Urophycis tenuis & $\mathrm{FL}=1.5250(\mathrm{OL}, \mathrm{mm})^{1.1456 \mathrm{c}}$ & $\mathrm{W}=0.003998(\mathrm{FL})^{3.1718 \mathrm{c}}$ \\
\hline American plaice Hippoglossoides platessoides & $\ln (\mathrm{FL})=4.0339+1.2425 \ln (\mathrm{OL}, \mathrm{cm})^{\mathrm{a}}$ & $\mathrm{W}=0.0023(\mathrm{FL})^{3.36 \mathrm{~b}}$ \\
\hline Yellowtail flounder Limanda ferruginea & $\mathrm{FL}=-6.979+6.709(\mathrm{OL}, \mathrm{mm})^{9}$ & $\mathrm{~W}=0.0023(\mathrm{FL})^{3.36 \mathrm{~b}}$ \\
\hline Witch flounder Glyptocephalus cynoglossus & & $W=0.0770(O L)^{4.633 d}$ \\
\hline Winter flounder Pseudopleuronectes americanus & $\mathrm{FL}=-8.559+8.389(\mathrm{OL}, \mathrm{mm})^{g}$ & $\mathrm{~W}=0.0079(\mathrm{FL})^{3.12 \mathrm{~b}}$ \\
\hline Sand lance Ammodytes spp. & $\mathrm{FL}=-4.377+9.024(\mathrm{OL}, \mathrm{mm})^{9}$ & $\mathrm{~W}=0.1248(\mathrm{FL})^{1.75 b}$ \\
\hline Redfish Sebastes spp. & $\ln (\mathrm{FL})=3.1273+1.1436 \ln (\mathrm{OL}, \mathrm{cm})^{\circ}$ & $W=0.0130(\mathrm{FL})^{3.06 \mathrm{~b}}$ \\
\hline Atlantic herring Clupea harengus & & $\log (W)=0.03+3.28 \log (O L)^{g}$ \\
\hline Capelin Mallotus villosus & & $\mathrm{W}=0.93(\mathrm{OL})^{3.05 \mathrm{e}}$ \\
\hline Squid Illex illecebrocus & & $\ln (\mathrm{W})=1.773+2.40 \ln (\mathrm{LRL}, \mathrm{mm})^{t}$ \\
\hline
\end{tabular}


that were within approximately $78 \mathrm{~km}$ of Sable Island. This is based on our estimate of the daily foraging range of grey seals around Sable Island. Recent satellite tracking data from 3 adult grey seals indicate a minimum average swimming speed of $0.9 \mathrm{~m} \mathrm{~s}^{-1}$ (McConnell et al. 1992). These data suggested that a grey seal might travel up to $78 \mathrm{~km} \mathrm{~d}^{-1}$. Based on food passage time in experiments on seals, we assumed that grey seals could have deposited faeces on Sable Island no more than $24 \mathrm{~h}$ after feeding (Prime 1979, Harvey 1989).

\section{RESULTS}

\section{Overall composition of the diet}

Otoliths, squid beaks and other hard parts, representing $\geq 24$ types of prey, were found in 365 of the 393 scats collected (Table 2). The 28 samples that con- tained no identifiable prey were distributed throughout all 8 months sampled, suggesting no pattern to their occurrence. Unidentified flatfishes, gadoids, and clupeids accounted for 158 of 791 or $20.0 \%$ of prey occurrences in the 365 scats containing prey hard parts. Only 36 fish occurrences could not be identified even to this level. Of the identified prey items, sand lance $(39.2 \%)$, silver hake Merluccius bilinearis $(6.8 \%)$ and Atlantic cod Gadus morhua (5.5\%) occurred most frequently. Sand lance dominated the diet in terms of the estimated number of individual prey consumed, followed by cod, redfish Sebastes spp., silver hake and capelin Mallotus villosus (Table 2). Expressed as percent wet weight, sand lance $(80.9 \%), \operatorname{cod}(11.0 \%)$, and silver hake $(2.6 \%)$ accounted for $94.5 \%$ of the identified prey consumed by grey seals over the study period (Table 2).

Unknown flatfish and otoliths from gadid species that are difficult to distinguish (i.e. cod, pollock and haddock) represented 81 and $42 \%$ of the total number of

Table 2. Halichoerus grypus, Frequency of occurrence, number of prey, number of otoliths and estimated wet weight (wt) of prey consumed by grey seals

\begin{tabular}{|c|c|c|c|c|c|c|c|c|}
\hline Species $^{a}$ & $\begin{array}{l}\text { No. of } \\
\text { ccurrences }\end{array}$ & $\begin{array}{l}\text { Percentage } \\
\text { occurrence }\end{array}$ & $\begin{array}{c}\text { Est. no. of } \\
\text { prey }\end{array}$ & $\begin{array}{c}\% \text { of total } \\
\text { prey }\end{array}$ & $\begin{array}{l}\text { No. of otoliths } \\
\text { found }\end{array}$ & $\begin{array}{l}\% \text { of otoliths } \\
\text { measured }\end{array}$ & $\begin{array}{c}\text { Est. prey } \\
\text { wt }(\mathrm{kg})\end{array}$ & $\begin{array}{c}\% \text { of } \\
\text { total wt }\end{array}$ \\
\hline Sand lance & 321 & 39.2 & 13838 & 93.3 & 27636 & 3.2 & 187.1 & 80.9 \\
\hline Atlantic cod & 45 & 5.5 & 140 & 0.9 & 254 & 31.9 & 25.5 & 11.0 \\
\hline Silver hake & 56 & 6.8 & 97 & 0.7 & 158 & 19.0 & 5.9 & 2.6 \\
\hline American plaice & 20 & 2.4 & 25 & 0.2 & 43 & 53.5 & 3.2 & 1.4 \\
\hline Redfish & 31 & 3.8 & 98 & 0.7 & 180 & 39.4 & 3.0 & 1.3 \\
\hline Yellowtail flounder & 22 & 2.7 & 28 & 0.2 & 43 & 62.8 & 2.5 & 1.1 \\
\hline Witch flounder & 4 & 0.5 & 5 & $<0.1$ & 9 & 55.6 & 1.0 & 0.4 \\
\hline Capelin & 16 & 2.0 & 72 & 0.5 & 133 & 21.8 & 0.9 & 0.4 \\
\hline Squid (beaks) & 6 & 0.7 & 11 & 0.1 & 14 & 35.7 & 0.7 & 0.3 \\
\hline Hake Urophycis spp. & 13 & 1.6 & 24 & 0.2 & 40 & 37.5 & 0.6 & 0.2 \\
\hline Pollock & 4 & 0.5 & 5 & $<0.1$ & 8 & 62.5 & 0.4 & 0.2 \\
\hline Atlantic herring & 3 & 0.4 & 3 & $<0.1$ & 3 & 100.0 & 0.4 & 0.2 \\
\hline Winter flounder & 1 & 0.1 & 1 & $<0.1$ & 1 & 100.0 & 0.1 & $<0.1$ \\
\hline Haddock & 2 & 0.2 & 3 & $<0.1$ & 3 & 100.0 & $<0.1$ & $<0.1$ \\
\hline Unknown flatfish & 98 & 12.0 & 251 & 1.7 & 444 & & & \\
\hline Unknown gadid & 59 & 7.2 & 114 & 0.8 & 190 & & & \\
\hline Unknown fish & 36 & 4.4 & 52 & 0.4 & 71 & & & \\
\hline Windowpane flounder ${ }^{b}$ & $r^{b} \quad 3$ & 0.4 & 5 & $<0.1$ & 8 & & & \\
\hline Mailed sculpin ${ }^{c}$ & 2 & 0.2 & 3 & $<0.1$ & 4 & & & \\
\hline Atlantic halibut ${ }^{d}$ & 1 & 0.1 & 1 & $<0.1$ & 2 & & & \\
\hline Ocean pout ${ }^{\mathrm{e}}$ & 1 & 0.1 & 1 & $<0.1$ & 2 & & & \\
\hline Atlantic sea raven & 1 & 0.1 & 1 & $<0.1$ & 2 & & & \\
\hline Unknown clupeid & 1 & 0.1 & 1 & $<0.1$ & 1 & & & \\
\hline Skate Raja spp. & 20 & 2.4 & 20 & 0.1 & & & & \\
\hline Clam spp. & 7 & 0.9 & 11 & 0.1 & & & & \\
\hline Sea urchin spp. & 10 & 1.2 & 10 & 0.1 & & & & \\
\hline Crab spp. & 6 & 0.7 & 6 & & & & & \\
\hline Shrimp spp. & 2 & 0.2 & 2 & & & & & \\
\hline No prey found & 28 & 3.4 & & & & & & \\
\hline Totals & 819 & 100.0 & 14828 & 100.0 & 29249 & 4.2 & 231.3 & 100.0 \\
\hline
\end{tabular}


otoliths recovered from these 2 taxa, respectively. We felt that excluding these otoliths from further analysis would tend to underestimate the importance of these prey in the diet. In the case of flatfish, we prorated the unknown flatfish by the proportion of each species in the identified sample each month to obtain an estimate of the total numbers of each flatfish species eaten. We then used the regressions of individual flatfish species in Table 1 to estimate the wet weight of the unidentified flatfish. Because the majority of the flatfish otoliths were unknown, we felt that it was more appropriate to express the final result simply as flatfish rather than by individual species. We used the same approach in dealing with the unknown gadids, but as most of these otoliths were identified as cod or pollock, we felt we could use individual species in subsequent analyses.

\section{Temporal variation}

Variation over the 8 sampled months in both the numbers and percent wet weight of prey species consumed is shown in Table 3. Sand lance accounted for between 87 and $96 \%$ of the total number of prey eaten by grey seals in all months sampled between July 1991 and January 1993. Cod, flatfish, silver hake and redfish combined accounted for another 4 to $10 \%$ of the number of prey eaten. Sand lance accounted for 49.7 to $85.3 \%$ of the food eaten by weight, followed by cod (1.6 to $44.1 \%$ ), flatfish ( 2.9 to $19.4 \%$ ) and silver hake (0 to $5.6 \%$ ).
With the exception of sand lance, the estimated number of individuals consumed within each month was insufficient to attempt statistical analysis of monthly variation. We used a logit model to investigate seasonal variation in the number of sand lance consumed. The model has the following form:

$$
\log \left[p_{i j k} /\left(1-p_{i j k}\right)\right]=\text { Mean }+ \text { Month effect }{ }_{k}+\varepsilon_{k}
$$

where $p$ is the proportion of prey species $i$ in scat $j$ in month $k$ and $\varepsilon_{k}$ is the error term. To test the null hypothesis of no month effect, we compared the change in deviance between the mean model and the model including month. The change in deviance of 129.1 with df 7 indicated a significant month effect. However, the residuals from the model exceeded those expected from a standard normal distribution, indicating that the data were overdispersed. This overdispersion may reflect the fact that samples tended to be collected in clusters (i.e. a number of samples collected on the same day). To account for this overdispersion, we used a scaled logit model in which the dispersion parameter (equal to 1 in the logit model) was estimated by fitting the model. The estimated dispersion parameter was 22.6. When the effect of this overdispersion was included in the model, there was no significant month effect $\left(\chi^{2}=5.71, \mathrm{df}=7, \mathrm{p}=0.57\right.$ ).

There was more evidence of temporal variation when the diet was expressed as percent wet weight of prey consumed (Table 3 ). Although statistical analysis of these data was not possible because we could only

Table 3. Seasonal variation in prey consumption by numbers $(\%)$ and weight $(\%)$

\begin{tabular}{|c|c|c|c|c|c|c|c|c|c|}
\hline \multirow[t]{2}{*}{ Species $^{a}$} & \multicolumn{3}{|c|}{$-1991-$} & \multicolumn{4}{|c|}{1992} & \multirow{2}{*}{$\begin{array}{c}1993 \\
\text { Jan }\end{array}$} & \multirow[t]{2}{*}{ Total } \\
\hline & Jul & Sep & Nov & Feb & Mar & May & Aug & & \\
\hline \multicolumn{10}{|l|}{ Prey numbers (\%) } \\
\hline Sand lance & 88.1 & 94.5 & 92.7 & 86.7 & 93.3 & 95.5 & 93.6 & 95.7 & 93.3 \\
\hline Atlantic cod & 2.8 & 2.5 & 2.4 & 0.5 & 1.1 & 0.2 & 2.4 & 0.8 & 1.7 \\
\hline Flatfish $^{\mathrm{b}}$ & 4.7 & 0.5 & 1.8 & 1.8 & 2.7 & 3.0 & 1.2 & 1.4 & 1.9 \\
\hline Silver hake & 2.3 & 1.1 & 0.6 & 0.1 & 0.1 & 0.1 & 1.3 & 0.0 & 0.7 \\
\hline Redfish & 1.2 & 0.0 & 0.6 & 3.8 & 0.7 & 0.4 & 0.5 & 0.1 & 0.7 \\
\hline Totals & 99.1 & 98.8 & 98.1 & 92.9 & 97.9 & 99.1 & 99.0 & 98.1 & 98.2 \\
\hline \multicolumn{10}{|l|}{ Prey weight (\%) } \\
\hline Sand lance & 56.0 & 49.7 & 75.1 & 78.7 & 76.1 & 77.8 & 67.2 & 85.3 & 69.2 \\
\hline Atlantic cod & 19.2 & 44.1 & 12.7 & 3.5 & 4.1 & 1.6 & 17.2 & 3.7 & 15.5 \\
\hline Flatfish $^{b}$ & 18.5 & 2.9 & 7.8 & 10.7 & 15.7 & 19.4 & 7.5 & 7.9 & 10.7 \\
\hline Silver hake & 5.0 & 3.1 & 1.5 & 0.4 & 0.2 & 0.1 & 5.6 & 0.0 & 2.2 \\
\hline Redfish & 1.2 & 0.0 & 0.4 & 2.7 & 2.4 & 0.7 & 1.5 & 0.4 & 1.1 \\
\hline Totals & 99.7 & 99.9 & 97.5 & 96.0 & 98.5 & 99.6 & 99.0 & 97.3 & 98.7 \\
\hline Total biomass $(\mathrm{kg})$ & 24.9 & 48.0 & 32.6 & 14.2 & 47.9 & 30.5 & 45.1 & 27.2 & 270.4 \\
\hline Sample size & 50.0 & 52.0 & 49.0 & 41.0 & 54.0 & 43.0 & 59.0 & 45.0 & 393.0 \\
\hline
\end{tabular}


obtain 1 sample within each month, the weight of sand lance in the diet appeared to increase from about 50 to $56 \%$ during the summer and fall of 1991 to between 75 and $79 \%$ during the winter and spring of 1992 , then declined to $67 \%$ in August 1992 before increasing to $85 \%$ in January 1993 (Fig. 2). The weight of cod in the diet appeared to be inversely related to that of sand lance, being higher in the summer than in the winter (Fig. 2). On the other hand, the weight of flatfish consumed appeared to be greater in the late winter through summer than during the fall (Fig. 2), whereas silver hake was most often eaten during the summer and early fall (Table 3).

\section{Diet in relation to prey abundance and distribution}

The distribution of fishing stations chosen from the trawl surveys in July 1991 and 1992 and in March 1992 to estimate prey abundance is illustrated in Fig. 1. We compared the ranks of the 10 most abundant species in the survey (expressed as $\mathrm{kg}$ wet weight) with the top 5 prey in the grey seal diet (expressed as \% wet weight) using faecal data from the same month, except for the July 1992 survey when we used an August faecal sample. These top 5 species accounted for $98.5 \%$ or more of the diet (Table 3). Unfortunately, the most frequently eaten prey, sand lance, is rarely caught in these research surveys such that we have no reliable index of abundance for this species. Bearing in mind that the first ranked prey (i.e. sand lance) in the grey seal diet was not represented in the survey data, there was a reasonably close correspondence between the survey rank and

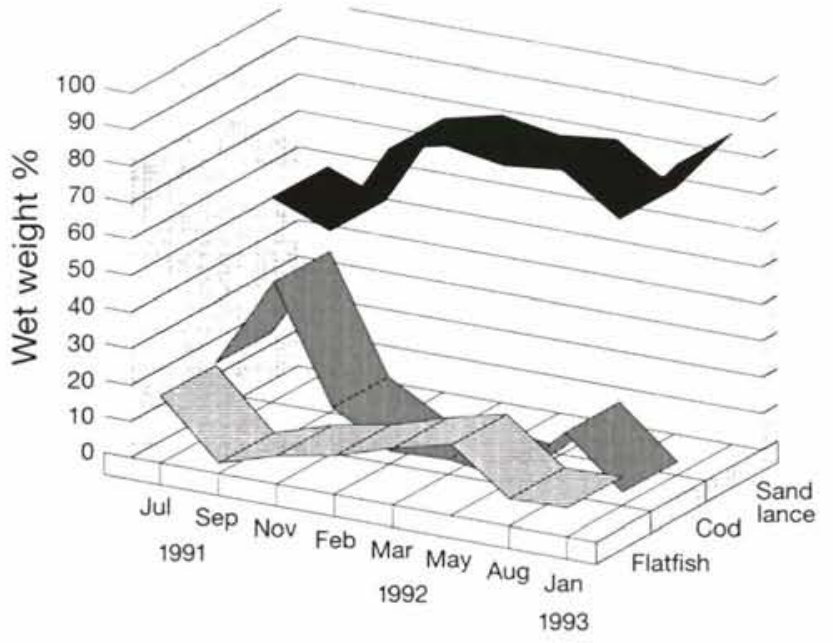

Fig. 2. Halichoerus grypus. Variation in the percent by wet weight of sand lance, Atlantic cod and flatfish [American plaice, flounders (yellow, winter, witch), Atlantic halibut] in the diet of grey seals foraging near Sable Island between July 1991 and January 1993. Genus and species given in Tables 1 \& 2

the rank in the diet for the second through fifth ranked prey types in the diet. However, there were exceptions as well (Table 4). Capelin ranked ninth in the survey but was the fifth ranked prey in the diet during March 1992. Similarly, in July 1992, silver hake ranked ninth in the survey but third in the diet. Despite its first place ranking in the 2 July trawl surveys, haddock was essentially not found in the grey seal diet. Prey that ranked higher in the diet tended to be not only abundant but more wide spread, as judged by the percentage of stations in which each prey was caught in the survey. Cod and flat-

Table 4. Halichoerus grypus. Comparisons of the ranks $(\mathrm{kg})$ of the top 10 species in research trawl surveys with the top 5 prey ${ }^{\circ}$ in grey seal diets ( $\%$ by wet weight). These 5 prey accounted for 98.5 to $99.7 \%$ of the diet. \% Occur.: percentage of occurrence

\begin{tabular}{|c|c|c|c|c|c|c|c|c|c|}
\hline \multirow[t]{3}{*}{ Species $^{b}$} & \multicolumn{3}{|c|}{ July 1991 ( $\mathrm{n}=22$ sets) } & \multicolumn{3}{|c|}{ March 1992 ( $\mathrm{n}=23$ sets $)$} & \multicolumn{3}{|c|}{ July 1992 ( $\mathrm{n}=24$ sets) } \\
\hline & \multicolumn{2}{|c|}{ Survey } & \multirow{2}{*}{$\begin{array}{l}\text { Diet } \\
\text { Rank }\end{array}$} & \multicolumn{2}{|c|}{ Survey } & \multirow{2}{*}{$\begin{array}{l}\text { Diet } \\
\text { Rank }\end{array}$} & \multicolumn{2}{|c|}{ Survey } & \multirow{2}{*}{$\begin{array}{l}\text { Diet } \\
\text { Rank }\end{array}$} \\
\hline & $\%$ Occur. & Rank & & $\%$ Occur. & Rank & & $\%$ Occur. & Rank & \\
\hline Haddock & 41 & 1 & & 26 & 7 & & 54 & 1 & \\
\hline Flatfish ${ }^{c}$ & 100 & 2 & 2 & 87 & 1 & 2 & 96 & 4 & 4 \\
\hline Redfish & 23 & 3 & 5 & 35 & 3 & 4 & 29 & 2 & 5 \\
\hline Atlantic cod & 86 & 4 & 3 & 48 & 6 & 3 & 67 & 3 & 2 \\
\hline Silver hake & 64 & 5 & 4 & 0 & & & 37 & 9 & 3 \\
\hline Sculpin $^{d}$ & 82 & 7 & & 78 & 5 & & 67 & 7 & \\
\hline Pollock & 27 & 8 & & 9 & 8 & & 37 & 8 & \\
\hline White hake & 23 & 9 & & 39 & 10 & & 25 & 5 & \\
\hline Capelin & 0 & & & 9 & 9 & 5 & 0 & & \\
\hline Atlantic herring & 0 & & & 35 & 4 & & 0 & & \\
\hline \multicolumn{10}{|c|}{$\begin{array}{l}\text { 'Sand lance is inconsistently caught in the trawl, therefore, we have no estimate of abundance of the number one ranked } \\
\text { prey in the diet } \\
\text { b Genus and species given in Table } 1 \& 2 \text { and as noted } \\
\text { c American plaice, flounders (yellowtail, winter, witch), Atlantic halibut } \\
{ }^{\mathrm{d}} \text { Myoxocephalus octodecemspinosus }\end{array}$} \\
\hline
\end{tabular}


fish occurred in an average of $81 \%$ (range 48 to $100 \%$ ) of the stations in each survey, compared to redfish, silver hake and capelin which on average occurred in only $33 \%$ (range 9 to $64 \%$ ) of the stations (Table 4 ).

\section{Prey size}

Estimated prey length distributions of 6 of the most common species eaten are given in Fig. 3. Sand lance and redfish were the smallest species eaten, with mean lengths of 15.0 and $11.7 \mathrm{~cm}$ and weights of 15 and $32 \mathrm{~g}$, respectively. Mean lengths of the other 4 species ranged between 20.4 and $24.5 \mathrm{~cm}$ (Fig. 3). The mean wet weight of cod eaten was $201 \mathrm{~g}$, followed by American plaice (132 g), yellowtail ( $89 \mathrm{~g}$ ) and silver hake (66 g).
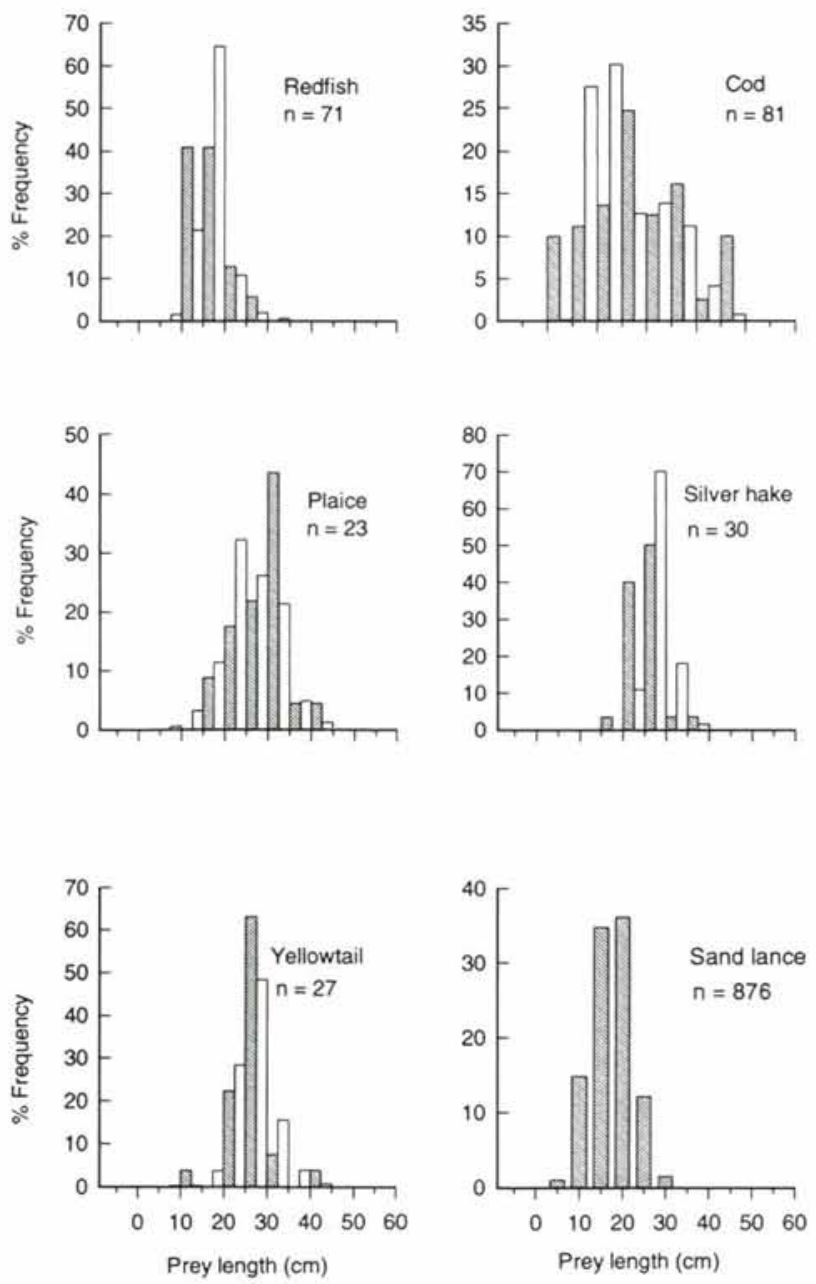

Fig. 3. Estimated prey length-frequency distributions of 6 species in the diet (hatched bars) of grey seals feeding in the vicinity of Sable Island and from the research trawl survey conducted in July 1992 (open bars). Sand lance were not caught in the survey. $\mathrm{n}$ : number of recovered otoliths measured in each species
We used the length-frequency distributions of species caught in the July 1992 research trawl survey to see if there was evidence that grey seals may select prey on the basis of length (Fig. 3). Based on these data, grey seals appeared to consume somewhat smaller redfish and silver hake than were caught by the research trawl. By contrast, the length distributions of cod, plaice and yellowtail in the diet were similar to those found in the trawl and did not suggest size-selective predation by grey seals. We have only considered qualitative comparisons at this time, because prey lengths derived from otoliths recovered in faeces may underestimate the actual length of prey consumed because of otolith erosion. There is insufficient data to be certain of the magnitude of this underestimation, but it is likely between 5 and $30 \%$ depending on the resistance of otoliths to digestion (see Pastukhov 1975. Harvey 1989). We found that the length of 3 robust gadoid sagittae (one each of cod, haddock and pollock) were reduced by about $6 \%$ after $24 \mathrm{~h}$ in $0.01 \mathrm{~N} \mathrm{HCl}$ ( $\mathrm{pH}$ of 2.0 to 2.5 ).

Only the data on sand lance were sufficient to examine monthly variation in the size of prey consumed by grey seals. Significant monthly differences were evident in both the mean length and wet weight of sand lance consumed $\left(F_{(1,7)}=16.6, \mathrm{p}<0.001\right.$ for length; $F_{(1,7)}=15.4, \mathrm{p}<0.001$ for weight). Smaller sand lance were consumed during August and September compared to other months of the year (Table 5).

\section{DISCUSSION}

\section{Sources of error}

Obtaining unbiased, quantitative estimates of the relative importance of different prey in the diet of grey seals is difficult for several reasons. First, grey seals often feed a considerable distance from shore, making it necessary to extrapolate the composition of diets derived from samples collected at haul-out sites over the entire species range. This would not present a problem if the diet was spatially homogeneous or if sampling sites were widely distributed throughout feeding areas. However, available data on grey seals (Benoit \& Bowen 1990, Hammond \& Prime 1990, Bowen et al. 1993) and other species (e.g. Perez \& Bigg 1986, Harkönen 1987) suggest that neither of these conditions is likely to occur. Second, it is usually not possible to know the sex, age or other characteristics of the seals represented by the faeces collected. Third, diets inferred from faeces have inherent sources of error that are not easily measured or accounted for.

These sources of error have received considerable attention but have been experimentally investigated only 
Table 5. Ammodytes dubius eaten by Halichoerus grypus. Monthly variation in the estimated mean length (cm) and wet weight $(\mathrm{g})$ of sand lance eaten by grey seals near Sable Island

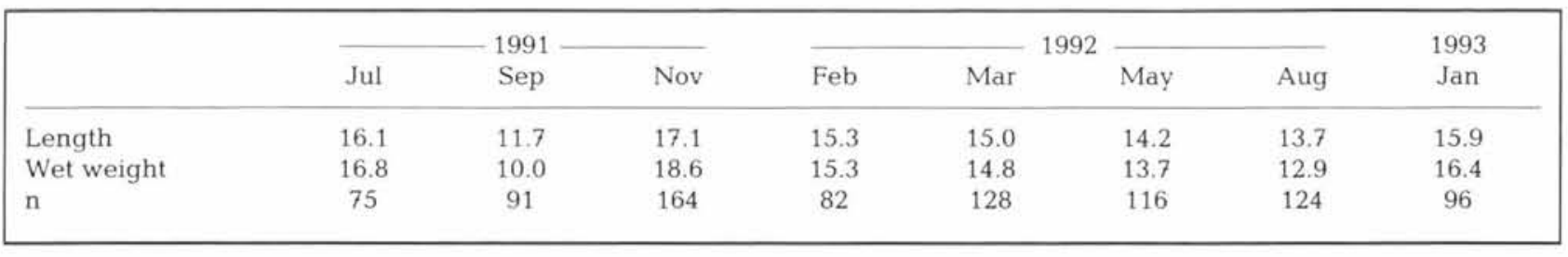

to a limited extent (e.g. Prime 1979, Pitcher 1980, da Silva \& Neilson 1985, Jobling \& Breiby 1986, Jobling 1987, Prime \& Hammond 1987, Dellinger \& Trillmich 1988, Harvey 1989). It is well known that otoliths recovered from seal faeces will have been partially digested, and thus reduced in size to some extent, during passage through the gut (da Silva \& Neilson 1985, Jobling \& Breiby 1986, Murie \& Lavigne 1986, Dellinger \& Trillmich 1988, Harvey 1989). This reduction in size will result in an underestimation of the length and particularly the wet weight of prey consumed (North et al. 1983, Jobling \& Breiby 1986, Dellinger \& Trillmich 1988). Several studies have attempted to derive correction factors for this reduction in otolith size based on feeding experiments with captive seals (Harvey 1989, Hammond \& Prime 1990). We have not used this type of correction for several reasons. First, digestion coefficients were not available for most of the species eaten by grey seals in our study. Second, those coefficients that do exist are based on measurements of otolith thickness and not otolith length as was measured in this study. We measured otolith length because length had been used to construct otolith vs fish length and fish weight relationships. Third, corrections of this nature are necessarily crude and do not account for the otoliths that are completely digested or digested to the point where species identification is not possible. Although we did not correct our measurements for the effect of digestion, we attempted to reduce the effect by measuring only those otoliths that retained much of their original shape and edge topography.

It is also possible that seals may not consume the heads of some fish. This is thought to occur particularly when large fish are eaten. Clearly, if this is a common practice our estimate of the composition of seal diets, based on otolith analysis, will be biased. Other prey such as skates do not have otoliths. Although their presence in the diet can be determined based on recovery of thorns, there is currently no way to relate the number or size of these thorns to the number or size of skates consumed. The result is that skates and many invertebrates will be under-represented in any analysis of recovered hard parts. Unfortunately, it is not possible to determine how serious these sources of error might be in the case of grey seals in our study.
Although faecal analysis is an important source of information about the diets of seals, it should be evident that some caution is needed in drawing conclusions about the size of prey taken by seals and the relative contribution of different species to the diet.

\section{Composition of the diet}

Despite the large number of taxa found in our samples (Table 2), only a small number of species accounted for most of the wet weight of prey consumed by grey seals foraging near Sable Island (Table 3 ). This reliance on a few prey species seems to be typical of grey seals at other locations in eastern Canada and Europe (McConnell et al. 1984, Benoit \& Bowen 1990, Hammond \& Prime 1990, Murie \& Lavigne 1992, Bowen et al. 1993) and of other pinnipeds (e.g. Frost \& Lowry 1980, Perez \& Bigg 1986, Pierce et al. 1991).

The importance of sand lance in the diet of grey seals foraging in the vicinity of Sable Island confirmed preliminary results of previous work (Bowen et al. 1993). Based on a small number of stomach samples collected at Sable Island during 1989, Bowen et al. (1993) estimated that sand lance accounted for about $33 \%$ of the summer diet and $75 \%$ of the winter diet by weight. These values are comparable to levels found in this study, although the data from our study suggest less temporal variation in the importance of sand lance. Sand lance is an important food of grey seals in other populations as well. McConnell et al. (1984), Hammond \& Prime (1990) and Prime \& Hammond (1990) reported that sandeels (Ammodytidae) accounted generally for a third or more of the food eaten by grey seals at different sites in the United Kingdom.

Cod and flatfish accounted for most of the remaining prey consumed by grey seals near Sable Island between July 1991 and January 1993 (Table 3). Although cod was also an important prey in stomach samples collected from Sable Island in 1989, flatfish accounted for little of the estimated wet weight of food eaten compared to silver hake and squid (Illex illecebrocus) (Bowen et al. 1993). In the case of squid, beaks may have been retained within the stomach such that they were under-represented in faeces (Harvey 1989) com- 
pared to the 1989 stomach data. Although we have no direct estimates, it is also possible that these differences reflect a change in the abundance of squid on the Scotian Shelf, as squid abundance varies greatly among years.

Temporal variation in the species composition of grey seal diets is well documented (Benoit \& Bowen 1990, Hammond \& Prime 1990, Bowen et al. 1993). Evidence of temporal variation in the relative importance of different species in the diet was apparent in this study as well (Table 3, Fig. 2). Although important throughout the year, sand lance accounted for a greater percentage of the diet by weight during the winter than during the summer months. Cod and silver hake were consumed primarily during the late summer and fall when both species move into shallower water over the offshore banks surrounding Sable Island. This temporal variation in the diet suggests a seasonal effect. However, additional data are needed to confirm that this pattern is indeed seasonal.

The results of our study also confirm that diet of grey seals foraging near Sable Island differs from that observed at haul-outs along the Nova Scotia mainland. At these inshore sites, Bowen et al. (1993) found that herring and mackerel replaced sand lance and flatfish as important foods. These differences are consistent with differences in the demersal fish assemblages near Sable Island compared to those nearer to the mainland (Mahon \& Smith 1989). Yellowtail flounder, an abundant member of the Eastern Banks assemblage, was also a significant prey of grey seals near Sable Island (about $50 \%$ of flatfish eaten by weight), but was absent from the diet near mainland sites (Bowen et al. 1993) where this species is uncommon. Research vessel survey results show that sand lance is most abundant on the offshore banks of the eastern Scotian Shelf but is uncommon nearer to the mainland (Simon \& Comeau in press).

\section{Factors affecting diet composition}

We know relatively little about the factors that affect the composition of grey seal diets. However, encounter rate between predator and prey, and prey profitability (defined as net energy value of prey divided by handling time; Stephens \& Krebs 1986) affect prey choice in other predators (e.g. Stephens \& Krebs 1986) and thus are likely to influence the composition of grey seal diets as well. Although we do not have the handling time data to estimate the relative profitability of prey to grey seals, the broad-scale spatial distribution, degree of clumping, and numerical abundance of prey in research trawl surveys can be used to roughly estimate possible differences in encounter rates between seals and their prey. Research, bottom-trawl surveys provide an index of relative abundance and coarse spatial distribution of some of the more common grey seal prey. Unfortunately, the species (i.e. sand lance) that accounted for most of the grey seal diet by weight is infrequently caught in these surveys, and thus we have no comparable estimate of sand lance abundance on the Scotian Shelf. Nevertheless, these surveys do show many of the largest catches of sand lance in the surveys were made in the vicinity of Sable Island (Simon $\&$ Comeau in press), suggesting that the species was relatively abundant in the study area. For other species, comparison of the rank abundance of other prey in survey data to that in grey seal diets suggests that more abundant species account for more of the diet than less abundant ones. Studies of other pinniped species also suggest that the abundance of prey is an important factor determining diet composition. For example, Bailey \& Ainley (1982) reported that the decline in sea lion Zalophus californianus predation on Pacific hake Merluccius productus was apparently related to a decline in the abundance of 2 to $4 \mathrm{yr}$ old hake, the most common ages eaten by sea lions. By contrast, when these age classes were abundant, hake dominated the sea lion diet. Sinclair et al. (1994) found that interannual variation in the importance of pollock Theragra chalcogramma in the diet of fur seals Callorhinus ursinus was positively related to year-class strength of pollock.

The absence of haddock from the grey seal diet is a notable exception to our observation that more abundant species were more prominent in the diet. It is possible that we failed to properly identify haddock otoliths, however, blind tests showed that one of us (G.D.H.) could reliably identify cod, haddock and pollock otoliths. A more likely explanation is that since most of the haddock caught in surveys came from stations near the southern limit of our estimated foraging range of grey seals, haddock meals may simply have not been observed in faeces collected on Sable Island. We might have expected to see more redfish in the diet, based on their abundance in the surveys, however, redfish catches were highly clumped (i.e. only a third or less of the research stations) and, like haddock, were caught at the edge of the area from which redfish otoliths were likely to have been found in faecal samples collected from the island.

The estimated length frequencies of prey eaten by grey seals in this study suggest that fish less than $40 \mathrm{~cm}$ are the main target of predation (Fig. 3). These data confirm the results of several other studies of grey seals (Benoit \& Bowen 1990, Hammond \& Prime 1990, Murie \& Lavigne 1992, Bowen et al. 1993). Thus, lengthspecific abundance may be a more sensitive measure of prey availability to seals than total abundance. The 
comparison of our otolith-reconstructed length frequencies to those from research trawl surveys indicated that grey seals apparently consumed smaller redfish and silver hake than were caught in the surveys. By contrast, the length distributions of cod, yellowtail flounder and American plaice eaten by seals were similar to those caught in the surveys. These results must be regarded as tentative because the small sample of prey lengths from the diet required us to compare survey data, taken over a single month, with diet data combined over the entire study period. Additional research is needed to clarify the extent to which grey seals show size-selective predation.

There can be little doubt that we face considerable difficulties in attempting to determine the diets of grey seals and other pinnipeds. Our Sable Island data likely provide a reasonable picture of the diet of grey seals on the offshore banks of the eastern Scotian Shelf, given that this area appears to represent a relatively homogeneous assemblage of demersal fishes (Mahon \& Smith 1989). However, grey seals foraging on the western Scotia Shelf will encounter different demersal fish assemblages (Mahon \& Smith 1989) from those on the eastern shelf, and therefore, we might expect the diet to differ from that reported here. Finally, given the potential for obtaining biased results from the use of otoliths and other hard parts, it is important that other methods be developed to complement the data obtained from current approaches. For example, Pierce et al. (1990b) have reported some success in the development of serological methods for prey identification. It may also be possible to determine the composition of seal diets based on the analysis of fatty acid signatures in lipids collected from seal tissues such as blood, blubber, and milk (Iverson 1988, 1993).

Acknowledgements. We are grateful to B. Beck for collecting the faecal samples from Sable Island and for recovering the otoliths and other hard parts from the samples in the laboratory. This study would not have been possible were it not for his efforts. S. Campana kindly provided access to his reference collection of otoliths from Scotian Shelf fishes. B. Beck and J. Hunt provided advice on prey identification. We thank $\mathrm{S}$. Smith and B. Field for suggesting the logit model and for help with the analysis. S. J. Iverson and K. Zwanenburg and 3 referees provided helpful comments on an earlier draft of the manuscript.

\section{LITERATURE CITED}

Bailey, K. M., Ainley, D. G. (1982). The dynamics of California sea lion predation on pacific hake. Fish. Res. 1: 163-176

Benoit, D., Bowen, W. D. (1990). Seasonal and geographic variation in the diet of grey seals (Halicheorus grypus) in eastern Canada. Can. Bull. Fish. Aquat. Sci. 222: 215-226

Bowen, W. D., Lawson, J. W., Beck, B. (1993). Seasonal and geographic variation in the species composition and size of prey consumed by grey seals (Halichoerus grypus) on the Scotian shelf. Can. J. Fish. Aquat. Sci. 50: 1768-1778

Clarke, M. R. (1986). A handbook for the identification of cephalopod beaks. Clarendon Press, Oxford

Clay, D., Clay, H. (1991). Determination of age and growth of white hake (Urophycis tenuis Mitchell) from the southern Gulf of St. Lawrence, Canada (including techniques for commercial sampling). Can. Tech. Rep. Fish. Aquat. Sci. No. 1828

da Silva, J., Neilson, J. (1985). Limitations of using otoliths recovered in scats to estimate prey consumption in seals. Can. J. Fish. Aquat. Sci. 42: 1439-1442

Dellinger, T., Trillmich, F. (1988). Estimating diet composition from scat analysis in otariid seals (Otariidae): is it reliable? Can. J. Zool. 66: 1865-1870

Frost, K. J., Lowry, L. F. (1980). Feeding of ribbon seal (Phoca fasciata) in the Bering Sea in spring. Can. J. Zool. 58: 1601-1607

Hammond, P. S., Prime, J. H. (1990). The diet of British grey seals (Halicheorus grypus) in eastern Canada. Can. Bull. Fish. Aquat. Sci. 222: 234-254

Harkönen, T. J. (1986). Guide to the otoliths of the bony fishes of the Northeast Atlantic. Danbiu ApS. Biological Consultants, Hellerup, Denmark

Harkönen, T. J. (1987). Seasonal and regional variations in the feeding habits of the harbour seal, Phoca vitulina, in the Skagerrak and the Kattegat. J. Zool., Lond. 213: 535-543

Harvey, J. T. (1989). Assessment of errors associated with harbour seal (Phoca vitulina) faecal sampling. J. Zool., Lond. 219: 101-111

Hunt, J. J. (1992). Morphological characteristics of otoliths for selected fish in the Northwest Atlantic. J. NW Atlant. Fish. Sci. 13: 63-75

Iverson, S. J. (1988). Composition, intake and gastric digestion of milk lipids in pinnipeds. Ph.D. thesis, University of Maryland, College Park

Iverson, S. J. (1993). Milk secretion in marine mammals in relation to foraging: can milk fatty acids predict diet? Symp. Zool. Soc. Lond. 66: 263-291

Jobling, M. (1987). Marine mammal faecal samples as indicators of prey importance - a source of error in bioenergetics studies. Sarsia 72: 255-260

Jobling, M., Breiby, A. (1986). The use and abuse of fish otoliths in studies of feeding habits of marine piscivores. Sarsia 71: 265-274

Mahon, R., Smith, R. W. (1989). Demersal fish assemblages on the Scotian Shelf, northwest Atlantic: spatial distribution and persistence. Can. J. Fish. Aquat. Sci. (Suppl. 1): 134-152

Mansfield, A. W., Beck, B. (1977). The grey seal in eastern Canada. Fish Mar. Serv. Tech. Rep. 704

McConnell, B. J., Chambers, C., Nicholas, K. S., Fedak, M. A. (1992). Satellite tracking of grey seals (Halichoerus grypus). J. Zool., Lond. 226: 271-282

McConnell, B. J., Prime, J. H., Hiby, A. R., Harwood, J. (1984). Grey seal diet. Natural Environmental Research Council, Cambridge

Murie, D. J., Lavigne, D. M. (1986). Interpretation of otoliths in stomach content analysis of phocid seals: quantifying fish consumption. Can. J. Zool. 64: 1152-1157

Murie, D. J., Lavigne, D. M. (1992). Growth and feeding habits of grey seals (Halichoerus grypus) in the northwestern Gulf of St. Lawrence, Canada. Can. J. Zool. 70: $1604-1613$

North, A. W., Croxall, J. P., Doidge, D. W. (1983). Fish prey of the Antarctic fur seal Arctocephalus gazella at South Georgia. Br. Antarct. Surv. Bull. 61: 27-37 
Olesiuk, P. F., Bigg, M. A., Ellis, G. M., Crockford, S. J., Wigen, R. J. (1990). An assessment of the feeding habits of harbour seals (Phoca vitulina) in the Strait of Georgia, British Columbia, based on scat analysis. Can. Tech. Rep. Fish. Aquat. Sci. No. 1730

Pastukhov, V. N. (1975). Number and distribution of the postparturent females of the Baikal seal. Morsk. Mlekopitayushchiye $41: 39-41$

Perez, M. A., Bigg, M. A. (1986). Diet of northern fur seals (Callorhinus ursinus) off western North America. Fish. Bull. U.S. 84: 957-971

Pierce, G. J., Boyle, P. R., Diack, J. S. W. (1991). Digestive tract contents of seals in Scottish waters: comparison of samples from salmon nets elsewhere. J. Zool., Lond. 225: $670-676$

Pierce, G. J., Boyle, P. R., Thompson, P. M. (1990a). Diet selection by seals. In: Barnes, M., Gibson, R. N. (eds.) Trophic relationships in the marine environment. Aberdeen University Press, Aberdeen, p. 222-238

Pierce, G. J., Diack, J. S. W., Boyle, P. R. (1990b). Application of serological methods to identification of fish prey in diets of seals and dolphins. J. exp. mar. Biol. Ecol. 137: 123-140

Pitcher, K. W. (1980). Stomach contents and faeces as indicators of harbor seal, Phoca vitulina, foods in the Gulf of Alaska. Fish. Bull. U.S. 78: 797-798

Prime, J. H. (1979). Observations on the digestion of some ganoid fish otoliths by a young common seal. Comm. Meet. int. Coun. Explor. Sea C.M.-ICES/N: 14

Prime, J. H., Hammond, P. S. (1987). Quantitative assessment of gray seal diet from faecal analysis In: Huntley, A. C.,

This article was submitted to the editor
Costa, D. P., Worthy, G. A. J., Castellini, M. A. (eds.) Approaches to marine mammal energetics. Allen Press, Lawrence, KS, p. 165-179

Prime, J. H., Hammond, P. S. (1990). The diet of grey seals from the south-western North Sea assessed from analyses of hard parts found in faeces. J. appl. Ecol. 27: 435-447

Ross, S.-A. (1992). Diet of the hooded seal, Cystophora cristata. M.Sc. thesis, Memorial Univ. of Newfoundland, St. John's

Simon, J. E., Comeau, P. A. (in press). Summer distribution and abundance trends of species caught on the Scotian Shelf from 1970-92, by the research vessel groundfish survey. Tech. Rep. Fish. Aquat. Sci. No. 1953

Sinclair, E., Loughlin, T., Pearcy, W. (1994). Prey selection by northern fur seals (Callorhinus ursinus) in the eastern Bering Sea. Fish. Bull. U.S. 92: 144-156

Snedecor, G. W., Cochrane, W. G. (1967). Statistical methods. Iowa State University Press, Ames

Stephens, D. W., Krebs, J. R. (1986) Foraging theory. In: Krebs, J. R., Clutton-brock, T. (eds.) Monographs in behavior and ecology. Princeton University Press, Princeton

Stobo, W. T., Zwanenburg, K. C. T. (1990). Grey seal (Halichoerus grypus) pup production on Sable Island and estimates of recent production in the Northwest Atlantic. Can. Bull. Fish. Aquat. Sci, 222: 171-184

Stobo, W. T., Beck, B., Horne, J. K. (1990). Seasonal movements of grey seals (Halichoerus grypus) in the Northwest Atlantic. Can. Bull. J. Fish. Aquat. Sci, 222: 199-213

Zwanenburg, K. C. T., Bowen, W. D. (1990). Population trends of the grey seal (Halichoerus grypus) in eastern Canada. Can. Bull. J. Fish. Aquat. Sci. 222: 185-197

Manuscript first received: November 9, 1993

Revised version accepted: June 22, 1994 